\title{
Major genes control hormone-induced ovulation rate in mice
}

\author{
J. L. Spearow* \\ Reproductive Endocrinology Program, and Department of Human Genetics, University of Michigan, \\ Ann Arbor, Michigan 48109, U.S.A. and Department of Meat and Animal Science, University of \\ Wisconsin, Madison, Wisconsin 53706, U.S.A.
}

\begin{abstract}
Summary. The present study examined the magnitude of genetic variation, mode of inheritance and number of loci controlling major genetic differences in hormoneinduced ovulation rate in mice. Mice were injected with 5 i.u. PMSG at 28 days of age and 5 i.u. hCG at 30 days, and hormone-induced ovulation rate was determined from counts of oviducal eggs in cumulus the next morning. Six-fold genetic differences in induced ovulation rate were detected amongst strains, ranging from a low mean ( \pm s.e.) value of $8.8( \pm 0.9)$ in $\mathrm{A} / \mathrm{J}$ up to $53.5( \pm 2.2)$ in $\mathrm{C} 57 \mathrm{BL} / 6 \mathrm{~J}$. The number of ova differed significantly amongst strains and amongst $\mathrm{F}_{1}$ crosses $(P<0.0001): 70 \%$ of the variation in hormone-induced ovulation rate was amongst strains. Of $9 \mathrm{~F}_{1}$ crosses examined, 4 showed positive heterosis, 3 showed no heterosis and 2 showed negative heterosis for hormone-induced ovulation rate. Analysis of parental, $F_{1}$ and $F_{2}$ generations revealed that the induced ovulation rate of $\mathrm{A} / \mathrm{J}$ and $\mathrm{C} 57 \mathrm{BL} / 6 \mathrm{~J}$ mice differed due to the action of about 3 or $4 \mathrm{loci}$, and A.SW/SnJ and SJL/J mice differed due to the action of about 2 to 3 loci. Analysis of recombinant inbred strains formed from $A / J$ and $\mathrm{C} 57 \mathrm{BL} / 6 \mathrm{~J}$ confirmed that these strains differed due to the action of a small number of loci. This study demonstrates the existence of a small number of major genes controlling hormone-induced ovulation rate in young mice.
\end{abstract}

Keywords: genes; ovulation rate; mice; heterosis

\section{Introduction}

The number of eggs ovulated at a given oestrus, or ovulation rate, is a function of the serum concentration of gonadotrophins and the ovarian sensitivity, or responsiveness to gonadotrophins (Spearow, 1980; Webb \& Gauld, 1985). Laboratory and farm animal species show a considerable amount of genetic variation in the ovarian responsiveness to exogenous gonadotrophins (Fowler \& Edwards, 1957; McLaren, 1962; Bradford, 1969; Land \& Falconer, 1969; Bradford et al., 1971; Bindon \& Pennycuik, 1974; Durrant et al., 1980; Spearow, 1980; Spearow \& Bradford, 1983). Unfortunately, the magnitude and nature of genetic variation in hormone-induced ovulation rate are not completely understood. Previous studies have been limited by the lack of highly inbred lines or well defined major breed differences in hormone-induced ovulation rate in most species. Furthermore, highly inbred strains which do differ dramatically in hormone-induced ovulation rate have not been used to determine whether genes with large effècts are involved.

The objectives of the present study were to determine (1) the magnitude of the genetic variation in hormone-induced ovulation rate by screening genetically defined, highly inbred strains of mice, (2) the nature of the genetic variation of hormone-induced ovulation rate in mice by examining the

*Present address: Department of Meat and Animal Science, University of Wisconsin, Madison, WI 53706, U.S.A. 
responses of recombinant inbred strains and $F_{1}$ crosses of these strains and, (3) the number of loci controlling these genetic differences in induced ovulation rate by comparing the performance of divergent inbred strains with their $F_{1}$ and $F_{2}$ crosses.

\section{Materials and Methods}

Lines and husbandry of mice. Highly inbred mouse strains A/J, AKR/J, CBA/J, SEC/1 ReJ, SWR/J, DBA/2J, BALB/ $\mathrm{cJ}, 129 / \mathrm{SvJ}, \mathrm{C} 3 \mathrm{H} / \mathrm{HeJ}, \mathrm{SM} / \mathrm{J}, \mathrm{C} 57 \mathrm{~L} / \mathrm{J}, \mathrm{C} 57 \mathrm{BL} / 10 \mathrm{~J}, \mathrm{SJL} / \mathrm{J}$ and $\mathrm{C} 57 \mathrm{BL} / 6 \mathrm{~J}$, and an $H-2$ congenic strain, A.Sw/SnJ, were obtained from the Jackson Laboratory (Bar Harbor, Maine, U.S.A.). Strains S15 and C17 were produced by more than 20 generations of full sib mating from the litter size line (Line Sl) and control line (Line C) in the laboratory of Dr G. E. Bradford (University of California at Davis). The development of strains $\mathrm{S} 15$ and $\mathrm{C} 17$ has been previously described by Spearow \& Bradford (1983). Several crosses amongst the above strains were also used. The recombinant inbred strains (AB5, AB13, AB15, AB17 and BA14) were developed by Dr Murriel Nesbitt by inbreeding from crosses of $\mathrm{A} / \mathrm{J}$ and $\mathrm{C} 57 \mathrm{BL} / 6 \mathrm{~J}$. These recombinant inbred strains were obtained from Dr Robert P. Erickson. Mice compared in each experiment were in groups that were as contemporary as possible. The performance of inbred strains and crosses was examined in an overlapping manner as mice became available from the breeding operation. Lights were on from 07:00 to $21: 00 \mathrm{~h}$, and the temperature was maintained at $22-24^{\circ} \mathrm{C}$. Mouse chow (Raiston Purina Company No. 5015) with an approximate analysis of $17 \%$ crude protein, $11 \%$ crude fat and $3 \%$ crude fibre was fed ad libitum.

Hormone-induced ovulation rate. PMSG was obtained from the hormone distribution program, NIADDK, National Institutes of Child Health and Human Development, Bethesda, MD. Human chorionic gonadotrophin with an activity of 2700 i.u./mg was obtained from Hypo Lab, Coinsins, Switzerland. Preliminary experiments were conducted to optimize the dose of gonadotrophins and the timing of their administration to mice for the detection of genetic variation. The protocol selected for all experiments described in this study consisted of (1) injecting 5 i.u. PMSG subcutaneously (s.c.) in $50 \mu \mathrm{l} 0.02 \mathrm{M}-\mathrm{NaPO}_{4}, 0.14 \mathrm{M}-\mathrm{NaCl}, 0.1 \%$ gelatin, $\mathrm{pH} 7.2$ (PBS-gel) at 28 days of age, (2) injecting 5 i.u. hCG in $50 \mu \mathrm{l} \mathrm{PBS}$-gel $48-52 \mathrm{~h}$ later (30 days of age) and (3) determining the number of ova with and without cumulus in the oviduct 16-22 h later (31 days of age). To do the latter, mice were weighed, killed by cervical dislocation and the number of freshly ovulated ova in cumulus (ova) and the number of ova without cumulus (old ova) were determined with the aid of a dissecting microscope. Lyophilysed samples of the same lot of PMSG and hCG were used for all experiments.

Preliminary experiments showed that any eggs ovulated by the first dose of gonadotrophins on Day 28 were in cumulus 16-22 h later on Day 29 but were all out of cumulus by Day 31. Since by Day 31 these eggs had been present in the oviduct for 2 days and were without cumulus, these ova were referred to as 'old ova'. Preliminary experiments also showed that freshly ovulated eggs were all in cumulus 16-22 h after hCG. Only eggs in cumulus on Day 31 were considered for calculation of hormone-induced ovulation rate.

In Exp. I, 16 strains of mice were screened to determine the magnitude of genetic variation in hormone-induced ovulation rate. In Exp. 2 the induced ovulation rate of several $F_{1}$ strain combinations was examined to determine the mode of inheritance of induced ovulation rate. Experiments 3 and 4 examined induced ovulation rate of several inbred strains and their $F_{1}$ and $F_{2}$ crosses to determine the number of loci mediating the observed genetic differences. In Exp. 5 , the induced ovulation rate of recombinant inbred strains of $\mathrm{A} / \mathrm{J}$ and $\mathrm{C} 57 \mathrm{BL} / 6 \mathrm{~J}$ were examined to confirm that the hormone-induced ovulation rate of these strains of mice differed due to the action of a small number of loci.

Statistical analysis. Data from Exps 1, 2 and 5 were analysed with one-way analyses of variance, covariance and multiple range tests. Since no dramatic differences in induced ovulation rate were readily apparent amongst the reciprocal crosses of the strains in Exp. 2, they were combined. In Exp. 2, since inbred strains were unrelated, the variance of the mid-parental average was estimated as $1 / 4$ variance $_{\mathrm{p}_{1}}+1 / 4$ variance $_{\mathrm{P2}}$. The variance of the difference between the $F_{1}$ mean and the mid-parental mean was calculated as (variance $\left.\mathrm{F}_{1} / \mathrm{n}-1\right)+\left(\right.$ variance $_{\text {midparental average }} /$ $n-1)$ (Snedecor \& Cochran, 1980). Significance of deviation of $F_{1}$ from the mid-parental mean was determined by $t$ test. Since the variances within strains for induced ovulation rate were not equal, ANOVAs were conducted on untransformed data using the Brown-Forsythe test (Brown \& Forsythe, 1974; Dixon, 1983) because it does not require the assumption of homogeneity of within-group variances. Furthermore log and square-root transformations were performed on the data. While a log transformation slightly improved the homogeneity of variances for hormoneinduced ovulation rate in some experiments, $\log$ correction was too extreme. Square-root transformation resulted in a much better homogeneity of variances amongst strains and crosses. Therefore data were also analysed after square-root transformation.

The number of loci (N) by which strains A/J and C57BL/6J (Exp. 3) and strains A.SW/SnJ and SJL/J (Exp. 4) differed with respect to hormone-induced ovulation rate was determined by the method of Wright (1968) for strains which are at extremes. With no dominance, $\mathrm{N}$ is equal to the segregation ratio (S), where:

$$
S=\frac{\left(\text { mean }_{\text {high sirain }}-\text { mean }_{\text {low strain }}\right)^{2}}{8\left(\text { variance }_{F_{2}}-\text { variance }_{\text {environment }}\right)}
$$

The environmental variance was estimated as that of the $F_{1}$ or that of the pooled variance within both parents and the $F_{1}$. With dominance $N=[1.5-2 \mathrm{~h}(1-\mathrm{h})] \mathrm{S}$. Where $\mathrm{h}$ was estimated as $\alpha_{1} /\left(\alpha_{1}+\alpha_{2}\right)$. The number of loci by which 
these strains of mice differed with respect to hormone-induced ovulation rate was determined both with and without square-root transformation of the data and utilizing the variance of the $F_{1}$ and using the pooled variance as estimates of the environmental variance.

\section{Results}

\section{Experiment 1: hormone-induced ovulation rate of inbred strains}

Figure 1 shows the number of ova ovulated by mice of 16 inbred strains in response to PMSG and hCG. Strains have been arranged in order of increasing hormone-induced ovulation rate. A tremendous amount of genetic variation in induced ovulation rate was detected. Some strains such as $\mathrm{A} / \mathrm{J}$ and $\mathrm{AKR} / \mathrm{J}$ ovulated a mean of about 9 eggs, while other strains such as $\mathrm{SJL} / \mathrm{J}$ and $\mathrm{C} 57 \mathrm{BL} / 6 \mathrm{~J}$ ovulated means of 47 and 54 eggs, respectively. The number of ova and square-root transformed ova differed significantly amongst strains $(P<0.0001)$ with $70.5 \%$ and $74.8 \%$ of the variation in ova and square-root ova being amongst strains, respectively.

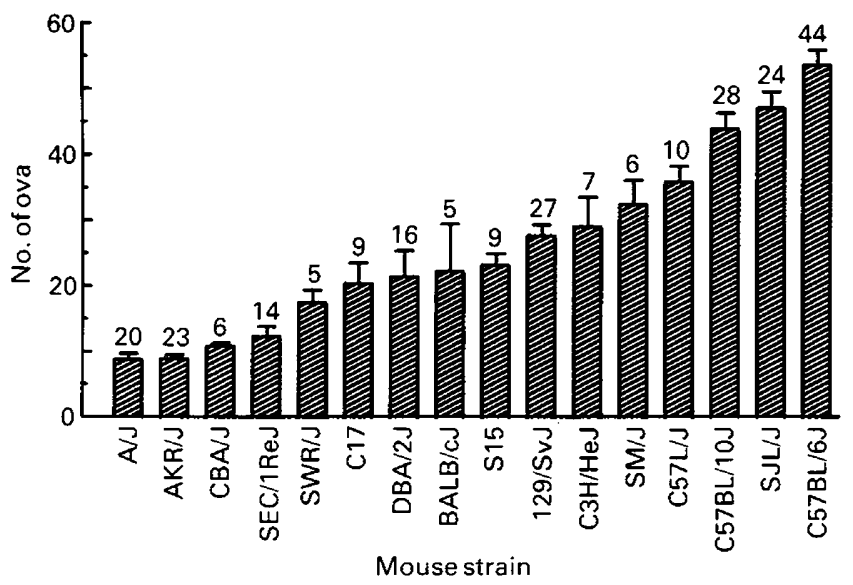

Fig. 1. Hormone-induced ovulation rate of mice of 16 inbred strains, i.e. no. of ova found in cumulus in response to 5 i.u. PMSG on Day 28 and 5 i.u. hCG on Day 30. Values are mean \pm s.e.m. for the no. of mice shown.

Body weight of mice at 31 days of age averaged $15.6 \mathrm{~g}$, but there were differences in mean body weight amongst strains $(P<0.001)$. The effect of body weight on hormone-induced ovulation rate was therefore tested. The regression of body weight on hormone-induced ovulation rate $(-1.38 \pm 0.34$ ova per $\mathrm{g}$ body weight $)$ was significant $(P<0.0001)$ and differed only marginally amongst strains $(P<0 \cdot 1)$. However, correction for the effect of body weight did not significantly change the ranking of any of the strains with respect to hormone-induced ovulation rate. After correction for body weight, $72 \%$ of the variation in induced ovulation rate was amongst strains.

Strains also differed in the number of old eggs matured by endogenous gonadotrophins and ovulated by the initial dose of PMSG $(P<0.0001)$ (Fig. 2). The number of old ova ovulated by $\mathrm{C} 57 \mathrm{BL} / 6 \mathrm{~J}$ in response to 5 i.u. PMSG was greater than that of $\mathrm{A} / \mathrm{J}(P<0.01), \mathrm{DBA} / 2 \mathrm{~J}(P<0.01)$, $129 / \mathrm{SvJ}(P<0.01)$ and SJL/J $(P<0.1)$ mice. Correction for the effect of body weight $(\mathrm{b}=$ $0.53 \pm 0.12$ old ova per $\mathrm{g}$ body weight; $P<0.001)$ did not significantly change the ranking of strains for old ova. 


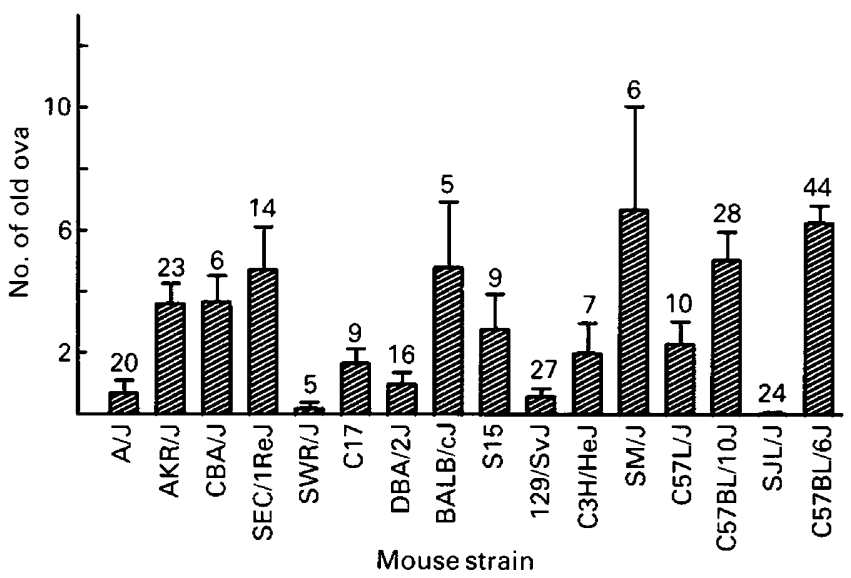

Fig. 2. Number of old ova found without cumulus in response to 5 i.u. PMSG on Day 28, and 5 i.u. hCG on Day 30 , in mice of different strains. Values are mean \pm s.e.m. for the no. of mice shown.

Table 1. Hormone induced ovulation rate of $F_{1}$ mice

\begin{tabular}{|c|c|c|c|c|c|}
\hline \multirow[b]{3}{*}{$F_{1}$ cross } & \multirow[b]{3}{*}{ No. } & \multicolumn{4}{|c|}{ Hormone induced ovulation rate } \\
\hline & & \multirow[b]{2}{*}{ Mean \pm s.e.m. } & \multirow[b]{2}{*}{$\begin{array}{l}\text { Mid-parental } \\
\text { average }\end{array}$} & \multicolumn{2}{|c|}{$\begin{array}{c}\text { Significance of } \\
\text { difference of } F_{1} \text { from: }\end{array}$} \\
\hline & & & & $\begin{array}{l}\text { Mid-parental } \\
\text { average }\end{array}$ & $\begin{array}{c}\text { Nearest } \\
\text { parent }\end{array}$ \\
\hline $\mathrm{A} / \mathrm{J} \times \mathrm{AKR} / \mathrm{J} \mathrm{F}_{1}$ & 10 & $17 \cdot 0 \pm 1 \cdot 7$ & 8.9 & ** & ** \\
\hline $\mathrm{A} / \mathrm{J} \times \mathrm{SEC} / 1 \operatorname{ReJ} \mathrm{F}_{1}$ & 22 & $14 \cdot 0 \pm 1 \cdot 3$ & $10 \cdot 5$ & * & NS \\
\hline $\mathrm{A} / \mathrm{J} \times \mathrm{DBA} / 2 \mathrm{~J} \mathrm{~F}_{1}$ & 10 & $23 \cdot 1 \pm 2 \cdot 9$ & $15 \cdot 1$ & $*$ & NS \\
\hline $\mathrm{A} / \mathrm{J} \times \mathrm{SJL} / \mathrm{J} \mathrm{F} \mathrm{F}_{1}$ & 12 & $23 \cdot 8 \pm 1 \cdot 3$ & 27.9 & NS & $* *$ \\
\hline $\mathrm{C} 57 \mathrm{BL} / 6 \mathrm{~J} \times \mathrm{A} / \mathrm{J} \mathrm{F}_{1}$ & 13 & $27 \cdot 2 \pm 2 \cdot 4$ & $31 \cdot 1$ & NS & ** \\
\hline $\mathrm{C} 57 \mathrm{BL} / 6 \mathrm{~J} \times \mathrm{AKR} / \mathrm{J} \mathrm{F}_{1}$ & 7 & $35 \cdot 3 \pm 3 \cdot 6$ & $31 \cdot 2$ & * & ** \\
\hline $\mathrm{C} 57 \mathrm{BL} / 6 \mathbf{J} \times \mathrm{DBA} / 2 \mathbf{J} \mathbf{F}_{1}$ & 27 & $25 \cdot 5 \pm 1.9$ & 37.4 & ** & NS \\
\hline $\mathrm{C} 57 \mathrm{BL} / 6 \mathrm{~J} \times 129 / \mathrm{SvJ} \mathrm{F}$ & 17 & $34 \cdot 6 \pm 2 \cdot 3$ & $40 \cdot 5$ & NS & * \\
\hline $\mathrm{C} 57 \mathrm{BL} / 6 \mathrm{~J} \times \mathrm{SJL} / \mathrm{J} \mathrm{F}_{1}$ & 16 & $37 \cdot 1 \pm 3 \cdot 4$ & $50 \cdot 2$ & ** & * \\
\hline
\end{tabular}

${ }^{*} P<0.05 ;{ }^{* *} P<0.01 ;$ NS $P>0.05$.

\section{Experiment 2: hormone-induced ovulation rate of $F_{1}$ strains of mice}

Table 1 shows the hormone-induced ovulation rate of $F_{1}$ mice that have been arranged in the order of increasing mid-parental average (i.e. the average of the two parental strains). Significant differences in hormone-induced ovulation rate were found amongst $\mathrm{F}_{1}$ mice $(P<0.0001)$. After square-root transformation of the data from $9 \mathrm{~F}_{1}$ crosses, 4 crosses $\left(\mathrm{A} / \mathrm{J} \times \mathrm{AKR} / \mathrm{J} \mathrm{F}_{1}, \mathrm{~A} / \mathrm{J} \times \mathrm{SEC} /\right.$ $1 \mathrm{ReJ} \mathrm{F}_{1}, \mathrm{~A} / \mathrm{J} \times \mathrm{DBA} / 2 \mathrm{~J} \mathrm{~F}_{1}$, and $\mathrm{C} 57 \mathrm{BL} / 6 \mathrm{~J} \times \mathrm{AKR} / \mathrm{J} \mathrm{F}_{1}$ ) showed positive heterosis, 3 crosses $\left(\mathrm{A} / \mathrm{J} \times \mathrm{SJL} / \mathrm{J} \mathrm{F}_{1}, \mathrm{C} 57 \mathrm{BL} / 6 \mathrm{~J} \times \mathrm{A} / \mathrm{J} \mathrm{F}_{1}\right.$ and $\left.\mathrm{C} 57 \mathrm{BL} / 6 \mathrm{~J} \times 129 / \mathrm{SvJ} \mathrm{F}_{1}\right)$ showed no heterosis, and 2 crosses $\left(\mathrm{C} 57 \mathrm{BL} / 6 \mathrm{~J} \times \mathrm{DBA} / 2 \mathrm{~J} \mathrm{~F}_{1}\right.$ and $\mathrm{C} 57 \mathrm{BL} / 6 \mathrm{~J} \times \mathrm{SJL} / \mathrm{J} \mathrm{F}_{1}$ ) showed negative heterosis (i.e. deviation from the mid-parental mean) for hormone-induced ovulation rate. The $A / J \times A K R / J F_{1}$ showed positive heterosis for hormone-induced ovulation rate $(P<0.001)$. Indeed the hormoneinduced ovulation rate of this $F_{1}$ was almost twice that of either parent. While the $A / J \times S E C /$ $1 \mathrm{ReJ} \mathrm{F}_{1}$ shows positive heterosis $(P<0.05)$, the observation that the induced ovulation rate of this $F_{1}$ was similar to that of the $\mathrm{SEC} / 1 \mathrm{ReJ}$ parent suggests dominance. The $\mathrm{C} 57 \mathrm{BL} / 6 \mathrm{~J} \times \mathrm{A} / \mathrm{J} \mathrm{F}_{1}$, the $\mathrm{A} / \mathrm{J} \times \mathrm{SJL} / \mathrm{JF}_{1}$ and the $\mathrm{C} 57 \mathrm{BL} / 6 \mathrm{~J} \times 129 / \mathrm{SvJ} \mathrm{F}_{1}$ showed no heterosis, since after $\log$ transformation 


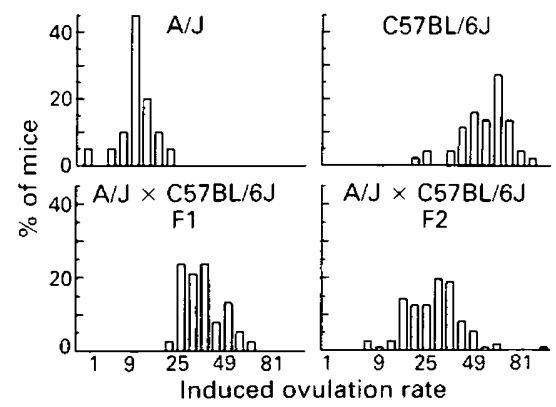

Fig. 3. Distribution of hormone-induced ovulation rate of $\mathrm{A} / \mathrm{J}$ and $\mathrm{C} 57 \mathrm{BL} / 6 \mathrm{~J}$ strains, and their $F_{1}$ and $F_{2}$ crosses.

the induced ovulation rate of these $\mathrm{F}_{1}$ crosses was not significantly different from the mid-parental values. While crosses involving DBA/2J showed heterosis, a closer look revealed that crosses with DBA/2J actually showed complete dominance. Regardless of whether DBA/2J was crossed with the lowest strain, $\mathrm{A} / \mathrm{J}$, or the highest strain, $\mathrm{C} 57 \mathrm{BL} / 6 \mathrm{~J}$, the induced ovulation rates of the resulting $F_{1}$ hybrids were the same as that of the DBA/2J parent. On the average, the $F_{1}$ crosses which had $\mathrm{A} / \mathrm{J}$ as a parent ovulated 2.3 more ova than their mid-parental average. In contrast, $F_{1} s$ which had $\mathrm{C} 57 \mathrm{BL} / 6 \mathrm{~J}$ as a parent ovulated $6 \cdot 2$ eggs less than their mid-parental average.

The body weight of $F_{1}$ mice averaged $15.9 \mathrm{~g}$ at 31 days of age, body weight at 31 days of age differed amongst $F_{1}$ crosses $(P<0.001)$, and the effect of body weight on induced ovulation rate differed significantly amongst $\mathrm{F}_{1}$ mice $(P<0.01)$.

For each $\mathrm{F}_{1}$ cross, the mean \pm s.e.m. number of old ova found in the oviduct on Day 31 was $6.8 \pm 2.3$ for $\mathrm{A} / \mathrm{J} \times \mathrm{AKR} / \mathrm{J} \mathrm{F}_{1} ; 7.7 \pm 1.6$ for $\mathrm{A} / \mathrm{J} \times \mathrm{SEC} / 1 \mathrm{ReJ} \mathrm{F}_{1} ; 4.6 \pm 1.4$ for $\mathrm{A} / \mathrm{J} \times \mathrm{DBA} / 2 \mathrm{~J}$ $\mathrm{F}_{1} ; 2.4 \pm 1.3$ for $\mathrm{A} / \mathrm{J} \times \mathrm{SJL} / \mathrm{J} \mathrm{F}_{1} ; 7.5 \pm 1.3$ for $\mathrm{C} 57 \mathrm{BL} / 6 \mathrm{~J} \times \mathrm{A} / \mathrm{J} \mathrm{F}_{1} ; 6.3 \pm 1.5$ for $\mathrm{C} 57 \mathrm{BL} /$ $6 \mathrm{~J} \times \mathrm{AKR} / \mathrm{J} \mathrm{F} \mathrm{F}_{1} ; 7.7 \pm 1.0$ for $\mathrm{C} 57 \mathrm{BL} / 6 \mathrm{~J} \times \mathrm{DBA} / 2 \mathrm{~J} \mathrm{~F} \mathrm{~F}_{1} ; 6.4 \pm 1.2$ for $\mathrm{C} 57 \mathrm{BL} / 6 \mathrm{~J} \times 129 / \mathrm{SvJ} \mathrm{F_{1 }}$; and $8.3 \pm 1.1$ for $\mathrm{C} 57 \mathrm{BL} / 6 \mathrm{~J} \times \mathrm{SJL} / \mathrm{J} \mathrm{F}_{1}$. The number of old ova did not differ significantly amongst $\mathrm{F}_{1}$ mice $(P=0 \cdot 14)$, and body weight did not have a significant effect $(P=0 \cdot 27)$.

\section{Experiment 3: number of loci differing amongst $A / J$ and $C 57 B L / 6 J$ mice}

The procedure of Wright (1968) was used to determine the number of loci mediating the 6-fold genetic differences between strains with low and high induced ovulation rates. This procedure uses the difference in the mean and variances of parents and their $F_{1}$ and $F_{2}$ crosses to estimate the number of loci. Figure 3 shows the distribution of the hormone-induced ovulation rate of strains $\mathrm{A} / \mathrm{J}$ and $\mathrm{C} 57 \mathrm{BL} / 6 \mathrm{~J}$ and their $\mathrm{F}_{1}$ and $\mathrm{F}_{2}$ crosses. The mean \pm s.d. hormone-induced ovulation rates were $8.8 \pm 4.0(\mathrm{~N}=20)$ for $\mathrm{A} / \mathrm{J}, 53 \cdot 5 \pm 14 \cdot 7(\mathrm{~N}=44)$ for $\mathrm{C} 57 \mathrm{BL} / 6 \mathrm{~J}, 32.9 \pm 10 \cdot 0(\mathrm{~N}=38)$ for $\mathrm{A} / \mathrm{J} \times \mathrm{C} 57 \mathrm{BL} / 6 \mathrm{~J} \mathrm{~F} \mathrm{~F}_{1}$ and $27 \cdot 3 \pm 13 \cdot 1(\mathrm{~N}=113)$ for $\mathrm{A} / \mathrm{J} \times \mathrm{C} 57 \mathrm{BL} / 6 \mathrm{~J} \mathrm{~F}_{2}$. The mean \pm s.d. square root transformed hormone-induced ovulation rates were $2.883 \pm 0.717$ for $\mathrm{A} / \mathrm{J}, 7.235 \pm 1.068$ for $\mathrm{C} 57 \mathrm{BL} / 6 \mathrm{~J}, 5.671 \pm 0.851$ for $\mathrm{A} / \mathrm{J} \times \mathrm{C} 57 \mathrm{BL} / 6 \mathrm{~J} \mathrm{~F}_{1}$ and $5.090 \pm 1.195$ for $\mathrm{A} / \mathrm{J} \times \mathrm{C} 57 \mathrm{BL} / 6 \mathrm{~J} \mathrm{~F}$. $_{2}$

Analysis of the untransformed data revealed estimates of 3.5 loci (using $F_{1}$ variance) and 3.96 loci (using the pooled variance) by which $\mathrm{A} / \mathrm{J}$ and $\mathrm{C} 57 \mathrm{BL} / 6 \mathrm{~J}$ differ. The same analysis of the square-root transformed data revealed estimates of 3.36 (using $F_{1}$ variance) and 3.63 (using the pooled variance) loci by which $\mathrm{A} / \mathrm{J}$ and $\mathrm{C} 57 \mathrm{BL} / 6 \mathrm{~J}$ differ. Inclusion of the effect of dominance in a model using the $F_{1}$ variance as an estimate of environmental variance resulted in estimates of 3.54 loci (raw data) and 3.49 loci (square root transformed data) by which strain $\mathrm{A} / \mathrm{J}$ and $\mathrm{C} 57 \mathrm{BL} / 6 \mathrm{~J}$ mice differ with respect to hormone-induced ovulation rate. Therefore, regardless of the assumptions used, the hormone-induced ovulation rate of $\mathrm{A} / \mathrm{J}$ and $\mathrm{C} 57 \mathrm{BL} / 6 \mathrm{~J}$ mice differed due to the action of approximately 3 to 4 loci. 
The results were also examined to determine whether these estimates of number of loci were highly dependent upon extreme outlying individuals. Even if data within each strain or cross were Winzorized to replace the most extreme outliers with the second most extreme outliers, $\mathrm{A} / \mathrm{J}$ and $\mathrm{C} 57 \mathrm{BL} / 6 \mathrm{~J}$ differed due to the action of $5 \cdot 2$ loci. Since estimates of number of loci differing between strains are highly dependent on the differences of the variances of crosses, the estimate obtained after Winzorization violates the assumptions of this method. Nevertheless, these data show that our estimates of number of loci controlling induced ovulation rate are not highly dependent on the extreme individuals.

\section{Experiment 4: number of loci by which A.SW/SnJ and SJL/J differ}

Since some $H$-2 haplotypes affect hormone-induced ovulation rate (Spearow et al., 1983), I decided genetically to dissect out or reduce this potential source of genetic variation by using a congenic substrain of strain A/WySnJ, specifically A.SW/SnJ. A.SW/SnJ is identical to A/J mice except for the $\mathrm{H}-2$ region on chromosome 17 , where $\mathrm{A} / \mathrm{J}$ is $\mathrm{H}-2^{\mathrm{a}}$ and $\mathrm{A} . \mathrm{SW} / \mathrm{SnJ}$ is $\mathrm{H}-2^{\mathrm{s}}$ (Altman \& Katz, 1979). Even though the H-2 regions of A.SW/SnJ and SJL/J come from different strains, and differ at the closely linked tla serological marker, both of these strains are $\mathbf{H}-2^{\text {s }}$ (Altman \& Katz, 1979). In essence, the $\mathrm{H}-2$ region of $\mathrm{A} . \mathrm{SW} / \mathrm{SnJ}$ is similar to that of SJL/J. Therefore, by crossing A.SW/SnJ and SJL/J to produce their $F_{1}$ and $F_{2}$ crosses, strain differences in hormone-induced ovulation rate could be examined which are largely independent of $\mathrm{H}-2$.

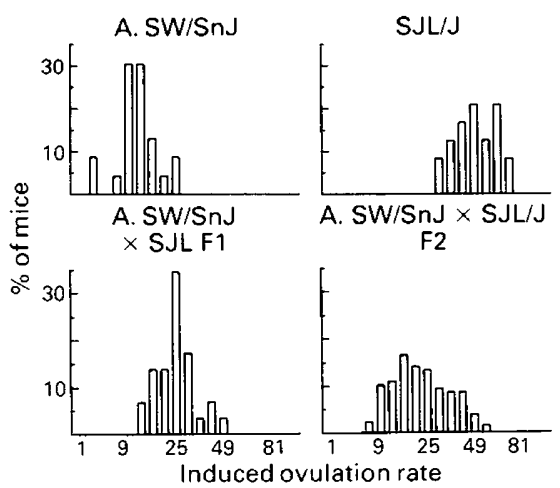

Fig. 4. Distribution of hormone-induced ovulation rate of $\mathrm{A} . \mathrm{SW} / \mathrm{SnJ}$ and $\mathrm{SJL} / \mathrm{J}$ strains, and their $F_{1}$ and $F_{2}$ crosses.

As shown in Fig. 4, the mean \pm s.d. hormone-induced ovulation rate was $10 \cdot 9 \pm 5 \cdot 6(\mathrm{~N}=23)$ for A.SW/SnJ, 47.0 $\pm 11.9(\mathrm{~N}=24)$ for SJL/J, $23.2 \pm 8.0(\mathrm{~N}=29)$ for A.SW/SnJ $\times \mathrm{SJL} / \mathrm{J} \mathrm{F}_{1}$, and $21.9 \pm 11.5(\mathrm{~N}=127)$ for $\mathrm{A} . \mathrm{SW} / \mathrm{SnJ} \times \mathrm{SJL} / \mathrm{J} \mathrm{F}_{2}$. After square-root transformation, the mean \pm s.d. hormone-induced ovulation rate was $3.191 \pm 0.874$ for A.SW/SnJ, $6.799 \pm 0.873$ for $\mathrm{SJL} / \mathrm{J}, \mathbf{4} \cdot 744 \pm 0.833$ for A.SW/SnJ $\times \mathrm{SJL} / \mathrm{J} \mathrm{F}_{1}$ and $4.523 \pm 1.203$ for $\mathrm{A} . \mathrm{SW} / \mathrm{SnJ} \times \mathrm{SJL} / \mathrm{J} \mathrm{F}_{2}$. The A.SW $/ \mathrm{SnJ} \times \mathrm{SJL} / \mathrm{J} \mathrm{F}_{1}$ cross showed $20 \%$ negative heterosis on a linear scale $(P<0.01)$, but no heterosis after square-root transformation. The variances of parentals and the A.SW/SnJ $\times \mathrm{SJL} / \mathrm{J}$ $F_{1}$ for square-root transformed induced ovulation rate were very similar, differing by less than $10 \%$. In contrast, the variance of square-root transformed hormone-induced ovulation rate for the A.SW $/ \mathrm{SnJ} \times \mathrm{SJL} / J \mathrm{~F}_{2}$ was twice that of either parent or the $\mathrm{F}_{1}$ cross. An analysis of untransformed induced ovulation rate resulted in estimates of 2.39 loci (using $F_{1}$ variance) and 2.88 loci (using the pooled variance) by which $\mathrm{A} . \mathrm{SW} / \mathrm{SnJ}$ and $\mathrm{SJL} / \mathrm{J}$ differ. An analysis of square-root transformed data revealed estimates of $2 \cdot 16$ (using $F_{1}$ variance) and $2 \cdot 26$ (using the pooled variance) loci by which A.SW/SnJ and SJL/J differ with respect to hormone-induced ovulation rate. Inclusion of the effect of 


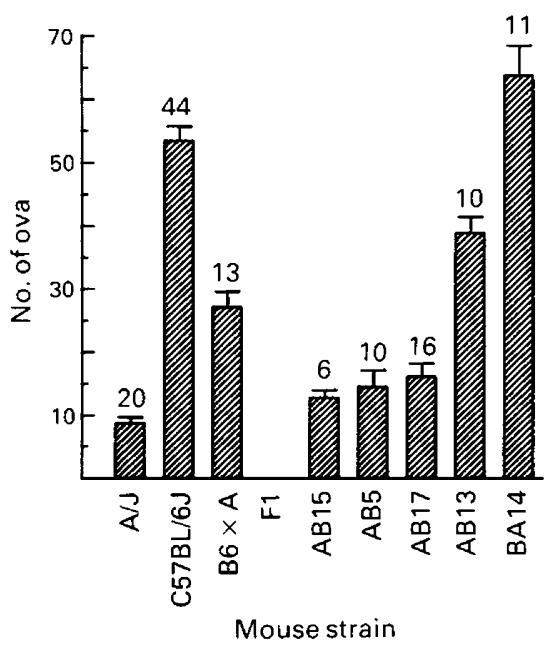

Fig. 5. Hormone-induced ovulation rate of mice of the $\mathrm{A} / \mathrm{J}$ and $\mathrm{C} 57 \mathrm{BL} / 6 \mathrm{~J}$ strains, $\mathrm{C} 57 \mathrm{BL} / 6 \mathrm{~J} \times$ $A / J F_{1}$ cross, and recombinant inbred mice produced from the $A / J$ and $C 57 \mathrm{BL} / 6 \mathrm{~J}$ strains. Values are mean \pm s.e.m. for no. of mice shown.

dominance in a model using the $F_{1}$ variance as an estimate of environmental variance resulted in estimates of 2.52 loci (raw data) and $2 \cdot 18$ (square-root transformed data) by which strains A.SW/ $\mathrm{SnJ}$ and $\mathrm{SJL} / \mathrm{J}$ mice differ with respect to hormone-induced ovulation rate. Thus, regardless of how these data are analysed, the results show that the induced ovulation rate of $\mathrm{A} . \mathrm{SW} / \mathrm{SnJ}$ and $\mathrm{SJL} / \mathrm{J}$ mice differ due to the action of 2 or 3 loci.

\section{Experiment 5: comparison of hormone-induced ovulation rate in recombinant inbred strains}

Recombinant inbred strains of $\mathrm{A} / \mathrm{J}$ and $\mathrm{C} 57 \mathrm{BL} / 6 \mathrm{~J}$ were examined to test independently whether the induced ovulation rate of mice of these strains differed due to the effect of a small number of major genetic loci. Hormone-induced ovulation rate (Fig. 5) differed amongst the recombinant inbred strains $(P<0.0001)$. Of the 5 recombinant inbred strains examined, 3 had a hormoneinduced ovulation rate near that of $A / J$, one had an induced ovulation rate near the $F_{1}$ and one near that of $\mathrm{C} 57 \mathrm{BL} / 6 \mathrm{~J}$. These results confirm that $\mathrm{A} / \mathrm{J}$ and $\mathrm{C} 57 \mathrm{BL} / 6 \mathrm{~J}$ mice differ by a small number of loci controlling hormone-induced ovulation rate.

\section{Discussion}

Screening the hormone-induced ovulation rate of mice of 16 inbred strains in Exp. 1 led to the discovery of a tremendous amount of genetic variation in this trait. The 5 -fold genetic differences in hormone-induced ovulation rate between $\mathrm{A} / \mathrm{J}$ and $\mathrm{SJL} / \mathrm{J}$ mice and 6-fold genetic differences in hormone-induced ovulation rate between $\mathrm{A} / \mathrm{J}$ and $\mathrm{C} 57 \mathrm{BL} / 6 \mathrm{~J}$ mice are considerably larger than the genetic differences previously reported for hormone-induced ovulation rate of mice (Fowler \& Edwards, 1957; Falconer et al., 1961; Bradford, 1969; Land \& Falconer, 1969; Wolfe, 1971; Land et al., 1974; Bindon \& Pennycuik, 1974; Durrant et al., 1980), sheep (Bradford et al., 1971) and cattle (Chupin et al., 1985). Nevertheless, screening widely divergent genotypes in other mammalian species may also reveal a magnitude of genetic variation in hormone-induced ovulation rate similar to that found in the present study.

The present study demonstrated the existence of genes with large effects on ovarian function. By administering large doses of exogenous gonadotrophins, the negative feedback controls on spontaneous ovulation rate were bypassed. Measurements of spontaneous ovulation rate would not 
have bypassed the negative feedback controls of serum gonadotrophins, and it is likely that much of the genetic variation in ovarian response to gonadotrophins would have escaped detection. It seems possible that the homeostatic mechanisms controlling ovulation rate may often hide genetic variation in reproductive function. I propose that (1) if complicated reproductive traits are broken down further and further into their components and (2) if feedback regulation controlling these traits is bypassed, other major genes controlling reproductive traits and their components will be identified.

The number of old eggs ovulated in Exp. 1 of the present study, or the number of fresh eggs ovulated by 5 i.u. hCG alone (Spearow, 1988), suggests that strain differences in the maturation of follicles by endogenous gonadotrophins, which can be ovulated by 5 i.u. PMSG or 5 i.u. hCG alone, is not a major contributor to genetic differences in hormone-induced ovulation rate. These results contrast with the findings of Eleftheriou et al. (1972), Eleftheriou \& Kristal (1974), and Spearow (1980) of large strain differences in ovulation rate induced by a single injection of gonadotrophin. Other studies suggest that the genetic differences in hormone-induced ovulation rate observed in the present study were due to genetic differences in the ovarian responsiveness to large doses of exogenous gonadotrophins (Spearow, 1988).

The present study suggests that induced ovulation rate does not fit an additive model. The magnitude and direction of dominance or heterosis in hormone-induced ovulation rate depended on the specific cross involved and differed greatly amongst crosses. The heterosis in $\mathrm{A} / \mathrm{J} \times \mathrm{SEC} /$ $1 \mathrm{ReJ} \mathrm{F}_{1}, \mathrm{~A} / \mathrm{J} \times \mathrm{DBA} / 2 \mathrm{~J} \mathrm{~F}_{1}$, and $\mathrm{C} 57 \mathrm{BL} / 6 \mathrm{~J} \times \mathrm{DBA} / 2 \mathrm{~J} \mathrm{~F}_{1}$ seemed actually to be due to complete dominance of one parent. The complete dominance of the $\mathrm{DBA} / 2 \mathrm{~J}$ parent was particularly striking since mice of the $\mathrm{A} / \mathrm{J}$ and $\mathrm{C} 57 \mathrm{BL} / 6 \mathrm{~J}$ strains had the lowest and highest hormone-induced ovulation rates, respectively.

The hormone-induced ovulation rate of the $\mathrm{A} / \mathrm{J} \times \mathrm{AKR} / \mathrm{J} \mathrm{F}_{1}$ was twice that of either parental inbred or the mid-parental average. This heterosis in hormone-induced ovulation rate could be due to one or more loci which show overdominance. Alternatively, the heterosis of the $A / J \times A K R / J F_{1}$ could be due to the complementation of the other strain's limitations at loci showing dominance. If this were the case, the hormone-induced ovulation rate of $A / J$ and $A K R / J$ would have been low due to different genetic limitations.

The $\mathrm{C} 57 \mathrm{BL} / 6 \mathrm{~J} \times \mathrm{SJL} / \mathrm{J} \mathrm{F}_{1}$ cross also showed true negative 'heterosis' in hormone-induced ovulation rate. The induced ovulation rate of this $F_{1}$ was lower than that of either parent or the mid-parental average. The results demonstrate that several crosses showed no dominance or heterosis for induced ovulation rate. The $\mathrm{C} 57 \mathrm{BL} / 6 \mathrm{~J} \times \mathrm{A} / \mathrm{J} \mathrm{F}_{1}$ showed no heterosis in hormone-induced ovulation rate in Exp. 2 or Exp. 3. After square-root transformation neither the $A / J \times S J L / J F_{1}$ nor the $\mathrm{C} 57 \mathrm{BL} / 6 \mathrm{~J} \times 129 / \mathrm{SvJ} \mathrm{F}_{1}$ showed heterosis in hormone-induced ovulation rate. Similarly, after square-root transformation, the $\mathrm{A} . \mathrm{SW} / \mathrm{SnJ} \times \mathrm{SJL} / \mathrm{J} \mathrm{F}_{1}$ did not show significant heterosis for induced ovulation rate. Thus, after correction for scale effects, it seems that these $F_{1}$ crosses show no dominance or heterosis.

The present study shows non-additive gene action controlling hormone-induced ovulation rate in some crosses but not in others. Clearly there is a large pool of genetic variation in hormoneinduced ovulation rate awaiting further investigation. Other investigators have mainly examined the genetics of natural or spontaneous ovulation rate. Spearow \& Bradford (1983) also found a small amount and Land et al. (1974) found a considerable amount of non-additive gene action controlling the natural ovulation rate of inbred strains of mice and rats, respectively. In contrast, in non-inbred lines of mice, natural ovulation rate has been shown to be controlled mainly by additive gene action (Bradford \& Nott, 1969; Land \& Falconer, 1969; Bradford et al., 1980; Spearow \& Bradford, 1983).

The broad sense heritability of hormone-induced ovulation rate in the present study seems to be much higher than that reported for most other reproductive traits. Since $70-75 \%$ of the variation in hormone-induced ovulation rate in Exp. 1 was amongst strains, these results suggest that hormoneinduced ovulation rate in mice has a high heritability in the broad sense. The present studies were 
conducted on inbred strains of mice and their crosses. Thus, the nature of the genetic variability amongst these specific inbred strains and their crosses could differ considerably from the genetic variability within non-inbred populations in other species. A particular major gene controlling hormone-induced ovulation rate may or may not be segregating in a given non-inbred population. Checking foundation or synthetic populations to confirm a high frequency of favourable alleles for induced ovulation rate before initiating selection should help to ensure rapid response to selection for this trait.

It has been generally assumed that most reproductive traits were controlled by many loci with small effects; i.e. that reproductive traits are quantitatively inherited (Falconer, 1960, 1981; Rice et al., 1970). For example, Eklund \& Bradford (1977) estimated that the 2-fold difference in litter size between a randomly selected strain of mice and a strain which had been selected for increased litter size was due to the action of between 54 and 164 loci. Nevertheless, major genes controlling reproductive traits have been detected. A major gene controls the ability of the male to induce ovulation in PMSG-primed mice (Eleftheriou et al., 1972). A major gene also controls bell or flashing-light facilitation of PMSG-induced ovulation in mice (Eleftheriou \& Kristal, 1974). The discovery that major genetic differences in the ovulation rate and litter size of sheep are due to the action of a single locus, the Booroola fertility locus (Piper \& Bindon, 1985), has attracted further interest in other genes having major effects on reproductive performance. The present study shows that major genes controlling reproductive performance are more common and more important than was previously thought.

The present study found that a small number of major genes control very large differences in hormone-induced ovulation rate in mice. The comparison of the parental strains, $F_{1}$ and $F_{2}$ crosses revealed that the 6 -fold differences in hormone-induced ovulation rate between $\mathrm{A} / \mathrm{J}$ and $\mathrm{C} 57 \mathrm{BL} / 6 \mathrm{~J}$ mice were due to the action of about 3 or 4 loci. These estimates are an approximation of the true number of loci differing between strains. Nevertheless, the recombinant inbred data clearly confirm that the genetic differences in hormone-induced ovulation rate between $\mathrm{A} / \mathrm{J}$ and $\mathrm{C} 57 \mathrm{BL} / 6 \mathrm{~J}$ are due to the action of a small number of loci. Spearow et al. (1983) have shown that one of these loci controlling hormone-induced ovulation rate for which $\mathrm{A} / \mathrm{J}$ and $\mathrm{C} 57 \mathrm{BL} / 6 \mathrm{~J}$ differ is located on chromosome 17 near the major histocompatibility locus $(\mathrm{H}-2)$. $\mathrm{H}-2$ congenic and recombinant inbred strains of $\mathrm{A} / \mathrm{J}$ and $\mathrm{C} 57 \mathrm{BL} / 6 \mathrm{~J}$ provide the genetic tools needed for dissecting out the biochemical and physiological mechanisms which mediate the observed genetic differences in hormone-induced ovulation rate between these two strains.

The present study found that the 5-fold difference in the hormone-induced ovulation rate of A.SW/SnJ and SJL/J was due to the action of about 2-3 loci. Regardless of the statistical assumptions utilized, the estimates of the number of loci differing between these two strains ranged from $2 \cdot 16$ to 2.88 loci, averaging 2.43 loci. While A.SW/SnJ and SJL/J mice are both $H-2^{\text {s }}$, due to the different origins of this $\mathrm{H}-2$ region in these strains of mice, it is not possible to eliminate fully a difference in $\mathrm{H}-2$ between these two strains of mice. Other results from this laboratory (not shown) have revealed that the hormone-induced ovulation rate of $\mathrm{A} / \mathrm{J}\left(H-2^{\mathrm{a}}\right)$ mice does not differ from that of $\mathrm{A} / \mathrm{WySnJ}\left(H-2^{\mathrm{a}}\right)$ or from A.SW/SnJ $\left(H-2^{\mathrm{sw}}\right)$ mice. This suggests that the 5 -fold differences in hormone-induced ovulation rate between $\mathrm{A} . \mathrm{SW} / \mathrm{SnJ}$ and $\mathrm{SJL} / \mathrm{J}$ mice, or between $\mathrm{A} / \mathrm{J}$ and $\mathrm{SJL} / \mathrm{J}$ mice, are both due to 2 or 3 loci.

The present study provides a foundation for more detailed studies on the genetic variation in the biochemical and physiological mechanisms controlling hormone-induced ovulation rate. Major 5- to 6-fold genetic differences in hormone-induced ovulation rate which are due to the action of a small number of loci are demonstrated and there is clearly a large pool of genetic variation in hormone-induced ovulation rate awaiting further investigation.

The present mouse model, along with the Booroola ' $F$ ' gene model in sheep (Bindon et al., 1985; Piper \& Bindon, 1985), should also provide valuable information on the physiological-genetic control of ovarian function in other species. While species may differ in the component traits which limit reproductive performance, the hormonal requirements for follicular maturation and ovulation 
and the mechanisms controlling follicular function are relatively similar across many mammalian species. The genetic differences in hormone-induced ovulation rate observed in the present study are likely to be indicative of the kinds of genetic variation in ovarian function present in other mammalian species. Striking differences in the ovarian response to exogenous gonadotrophins have also been found within sheep, cattle and human populations (Bradford et al., 1971; Jones, 1984). Unfortunately, well defined genetic models for examining hormone-induced ovulation rate are not available for many mammalian species. Therefore, once species differences in physiological controls are considered, information obtained about genetic differences in the control of hormone-induced ovulation rate in these strains of mice should be applicable to other species. A better understanding of the genetic variation in ovarian response to gonadotrophins could enhance the development of (1) improved hormonal treatments for obtaining the desired ovulation rate in livestock and humans and (2) improved selection criteria for breeding for increased ovulation rate in livestock species either through gene transfer procedures or conventional animal breeding techniques.

I thank Dr A. Rees Midgley and Dr Robert P. Erickson for their support and encouragement; Dr Robert Kemp, Dr Scott Newman and Julie Busby for review of this manuscript; and NIADDK for PMSG. This work was supported by the Reproductive Endocrinology Program and Department of Human Genetics, University of Michigan; by the College of Agricultural and Life Sciences, University of Wisconsin; by NIH Grant (HD18889-02); and by Hatch Grant No. WIS2848.

\section{References}

Altman, P.L. \& Katz, D.D. (1979) Inbred and Genetically Defined Strains of Laboratory Animals. Part 1, Mouse and Rat. Federation of American Societies for Experimental Biology, Bethesda.

Bindon, B.M. \& Pennycuik, P.R. (1974) Differences in ovarian sensitivity of mice selected for fecundity. $J$. Reprod. Fert. 36, 221-224.

Bindon, B.M., Piper, L.R., Cummins, L.J., O'Shea, T., Hillard, M.A., Findlay, J.K. \& Robertson, D.M. (1985) Reproductive endocrinology of prolific sheep: studies of the Booroola Merino. In Genetics of Reproduction in Sheep, pp. 217-235. Eds R. B. Land \& D. W. Robinson. Butterworths, London.

Bradford, G.E. (1969) Genetic control of ovulation rate and embryo survival in mice. I. Response to selection. Genetics, Princeton 61, 905-921.

Bradford, G.E. \& Nott, C.F.G. (1969) Genetic control of ovulation rate and embryo survival in mice. Il. Effects of crossing selected lines. Genetics, Princeton 63, 907-918.

Bradford, G.E., Quirke, J.F. \& Hart, R. (1971) Natural and induced ovulation rate of Finnish Landrace and other breeds of sheep. Anim. Prod. 13, 627-635.

Bradford, G.E., Barkley, M.S. \& Spearow, J.L. (1980) Physiological effects of selection for aspects of efficiency of reproduction. In Selection Experiments in Laboratory and Domestic Animals, pp. 161-173. Ed. A. Robertson. Commonwealth Agricultural Bureaux, E.A.A.P., Harrowgate.

Brown, M.A. \& Forsythe, A.B. (1974) The small sample behavior of some statistics which test the equality of several means. Technometrics 16, 129-132.

Chupin, D., Combarnous, Y. \& Procureur, R. (1985) Different effect of LH on FSH-induced superovulation in two breeds of cattle. Theriogenology 23, 184-184.

Dixon, W.J. (1983) Description of groups with histo- grams and analysis of variance. In BMDP Statistical Software, pp. 105-115. Ed. W. J. Dixon. Univ. of California Press, Berkley.

Durrant, B.S., Eisen, E.J. \& Ulberg, L.C. (1980) Ovulation rate, embryo survival and ovarian sensitivity to gonadotrophins in mice selected for litter size and body weight. J. Reprod. Fert. 59, 329-339.

Eklund, J. \& Bradford, G.E. (1977) Genetic analysis of a strain of mice plateaued for litter size. Genetics, Princeton 85, 529-542.

Eleftheriou, B.E. \& Kristal, M.B. (1974) A gene controlling bell- and photically-induced ovulation in mice. $J$. Reprod. Fert. 38, 41-47.

Eleftheriou, B.E., Bailey, D.W. \& Zarrow, M.X. (1972) A gene controlling male pheromonal facilitation of PMSG-induced ovulation in mice. J. Reprod. Fert. 31, 155-158.

Falconer, D.S. (1960) The genetics of litter size in mice. $J$. Cell. comp. Physiol. 56 (Suppl. 1), 153-167.

Falconer, D.S. (1981) Introduction to Quantitative Genetics, 2nd edn. Longman Group Limited, London.

Falconer, D.S., Edwards, R.G., Fowler, R.E. \& Roberts, R.C. (1961) Analysis of differences in the numbers of eggs shed by the two ovaries of mice during natural oestrus or after superovulation. J. Reprod. Fert. 2, $418-437$.

Fowler, R. \& Edwards, R.G. (1957) Induction of superovulation and pregnancy in mature mice by gonadotrophins. J. Endocr. 15, 374-384.

Jones, G.S. (1984) Update on in vitro fertilization. Endocr. Rev. 5, 62-75.

Land, R.B. \& Falconer, D.S. (1969) Genetic studies of ovulation rate in the mouse. Genet. Res. 13, 25-46.

Land, R.B., de Reviers, M.M., Thompson, R. \& Mauléon, P. (1974) Quantitative physiological studies of genetic 
variation in the ovarian activity of the rat. $J$. Reprod. Fert. 38, 29-39.

McLaren, A. (1962) The relationship between natural fecundity and response to follicle stimulating hormone. J. Endocr. 25, 137-144.

Piper, L.R. \& Bindon, B.M. (1985) The single gene inheritance of the high litter size of the Booroola Merino. In Genetics of Reproduction in Sheep, pp. 115-125. Eds R. B. Land \& D. W. Robinson. Butterworths, London.

Rice, V.A., Andrews, F.N., Warwick, E.J. \& Legates, J.E. (1970) Breeding and Improvement of Farm Animals, 6th edn. McGraw-Hill, New York.

Snedecor, G.W. \& Cochran, W.G. (1980) Statistical Methods, 7 th edn. Iowa State University Press, Ames.

Spearow, J.L. (1980) The physiological basis of genetic differences in the ovulation rate of mice. Ph.D. thesis, University of California. [Diss. Abstr. No. 8027089.]

Spearow, J.L. (1988) Characterization of genetic differ- ences in hormone-induced ovulation rate in mice. $J$. Reprod. Fert. 82, 799-806.

Spearow, J.L. \& Bradford, G.E. (1983) Genetic variation in spontaneous ovulation rate and $\mathbf{L H}$ receptor induction in mice. J. Reprod. Fert. 69, 529-537.

Spearow, J.L., Erickson, R.P., Midgley, A.R., Herbon, L., Fields, S. \& Malone, E. (1983) Effect of H-2 on hormone induced ovulation rate and $\mathrm{LH}$ receptor induction. Endocrinology 112 (Suppl.), Abstr. 47.

Webb, R. \& Gauld, I.K. (1985) Folliculogenesis in sheep: control of ovulation rate. In Genetics of Reproduction in Sheep, pp. 261-274. Eds R. B. Land \& D. W. Robinson. Butterworths, London.

Wolfe, H.G. (1971) Genetic influence on gonadotropic activity in mice. Biol. Reprod. 4, 161-173.

Wright, S.(1968) Evolution and the Genetics of Populations: Vol. 1, Genetic and Biometrical Foundations. University of Chicago Press.

Received 16 September 1987 